\title{
VARIATION OF THE ANAL RESTING PRESSURE INDUCED BY POSTEXPIRATORY APNEA EFFORT IN PATIENTS WITH CONSTIPATION
}

\author{
Thaís Helena BENETTI ${ }^{1}$, Maria Fernanda SANTOS ${ }^{1}$, Melissa Eichenberger Alves MERGULHÃ ${ }^{1}$, \\ João José FAGUNDES², Maria de Lourdes Setsuko AYRIZONO² and \\ Cláudio Saddy Rodrigues COY²
}

\begin{abstract}
Context - Intestinal constipation - a common symptom among the general population - is more frequent in women. It may be secondary to an improper diet or organic or functional disturbances, such as dyskinesia of the pelvic floor. This is basically characterized by the absence of relaxation or paradoxical contraction of the pelvic floor and anal sphincter during evacuation. Objective - To analyze, by manometric data, the anal pressure variation at rest, during evacuation effort by using the Valsalva maneuver and forced post-expiratory apnea in subjects with secondary constipation. Methods - Twenty-one patients (19 females - 90.4\%) with a mean age of 47.5 years old (23-72) were studied. The diagnosis was performed using anorectal manometry, with a catheter containing eight channels disposed at the axial axis, measuring the proximal (1) and distal (2) portions of the anal orifice. The elevation of the pressure values in relation to the resting with the evacuation effort was present in all patients. The Agachan score was used for clinical evaluation of constipation. The variables studied were: mean anal pressure of the anal orifice for 20 seconds at rest, the effort of evacuation using Valsalva maneuver and the effort of evacuation during apnea after forced expiration, as well as the area under the curve of the manometric tracing at moments Valsalva and apnea. Results - The analysis of the mean values of the anal pressure variation at rest evidenced difference between proximal and distal channels $(P=0.007)$, independent of the moment and tendency to differ during moments Valsalva and apnea $(P=0.06)$. The mean of values of the area under the manometric tracing curve showed differences between moments Valsalva and apnea $(P=0.0008)$, either at the proximal portion or at the distal portion of the anal orifice. Conclusion - The effort of evacuation associated with postexpiratory apnea, when compared with the effort associated with the Valsalva maneuver, provides lower elevation of anal pressure at rest by the parameter area under the curve.
\end{abstract}

HEADINGS - Constipation. Manometry. Dyskinesia.

\section{INTRODUCTION}

Constipation is a common symptom in consultation rooms, which can be detrimental to quality of life and difficult to solve in some cases. A symptomatic approach is usually maintained this however often turns the patients into chronic laxative users, without a definitive solution and in some cases with a worsening of symptoms.

Functional evacuation disorders that lead to constipation are not completely understood. Among these disorders, there is the occurrence of dyskinesia of the pelvic floor, characterized by the contraction of lifting muscles and external sphincter of the anus during evacuation, a condition that receives several names, such as paradoxical contraction of the puborretal muscle, obstructed evacuation or anismus $^{(3,4,7,14,21,27)}$.

The term anismus was initially used by Wasserman ${ }^{(27)}$ in a study with four patients presenting constipation and spasms of the external sphincter of the anus. Functional change is frequent, though underestimated as a cause of chronic constipation and studies report that $50 \%$ of the individuals suffer from constipation $^{(15,16,26)}$. The condition is characterized by a difficulty in initiating the evacuation, a sensation of incomplete evacuation with or without the need of digital maneuvers in order to empty the rectum ${ }^{(5)}$, secondary to failure of relaxation of the puborretal and external anal sphincter muscles or contraction

Coloproctology Group, Discipline of Disorders of the Digestive Tract, Department of Surgery, Faculty of Medical Sciences, University of Campinas - FCM-UNICAMP,

1 Campinas, SP, Brazil.

1 Post Graduation, Department of Surgery - FCM-UNICAMP; ${ }^{2}$ Discipline of Disorders of the Digestive Tract, Department of Surgery - FCM-UNICAMP.
Correspondence: Dr. Thaís Helena Benetti - Rua Nossa Senhora de Fátima, 740 - 14700-000 - Bebedouro, SP, Brazil. E-mail: thaishbenetti@hotmail.com 
during the evacuation effort ${ }^{(2,3,25)}$. The lack of relaxation of the puborretal muscle during evacuation can be observed in normal individuals ${ }^{(6,17,21,25)}$ however, the history of a difficulty to initiate evacuation, chronic use of laxatives, suppositories and enemas are indicative of obstructed evacuation due to functional disorders ${ }^{(28)}$.

During the effort of evacuation a reduction of the anal canal pressure and electrical activity is expected ${ }^{(15)}$ and it is known that the pelvic floor muscles tend to contract in certain tasks that increase intra-abdominal pressure to contribute to the maintenance of continence. In normal subjects, the cough causes significant elevation of the anal canal pressure accompanied by an increase in electrical activity of muscles.

Considering the high prevalence of functional changes in the genesis of constipation, the aim of this study is to evaluate the variation of anal canal pressure in patients with constipation with Valsalva maneuver and forced postexpiratory apnea during evacuation effort. This knowledge could play important role in the treatment promoting more conservative therapy such as biofeedback.

\section{METHODS}

A population of patients from the coloproctology outpatient clinic of the State University of UNICAMP Campinas, SP, Brazil - participated in this study, from May to December 2005 with a diagnosis for constipation and elevation of the pressure values in relation to the resting with the evacuation effort. Agachan score was used for clinical evaluation. Twenty-one patients with an average age of 47.5 (23-72) years, 19 of which were females participated in this study (Table 1).

The parameters analyzed in this study were obtained by manometric analysis of the average anal resting pressure followed by the evacuation effort with the Valsalva maneuver and return to rest, followed by evacuation efforts with postexpiratory apnea.

To perform anorectal manometry an eight-channel polygraph (Synetics) was used, coupled to a pneumohydraulic infusion system and axial catheter of eight channels. For the analysis of pressure values specific computer programs were used (Gastrosoft, lower GI, version 6.31).

\section{Definition of variables}

Manometric variables were obtained in the proximal (1) and distal (2) regions of the anal canal. Only two channels, which showed higher-pressure gradient, located in different regions of the anal canal (proximal and distal), were considered for analysis and there could be channel variation between individuals. The analysis of the variables was performed in conditions of rest (R), evacuation effort with the Valsalva maneuver (V) and evacuation effort with postexpiratory apnea (A). Such conditions were defined as evaluation moments performed comparatively between portions 1 and 2 of the anal canal.

\section{The parameters analyzed were:}

- Average of resting anal pressure in the proximal (R1) and distal (R2) regions of the anal canal;

TABLE 1. General casuistic relation

\begin{tabular}{|c|c|c|c|c|c|c|}
\hline Individual & Age & Gender & History (years) & Intestinal habit & Use of laxatives & Agachan score \\
\hline 1 & 42 & $\mathrm{~F}$ & 10 & $1 \times 10 \mathrm{D}$ & $\mathrm{Y}$ & 18 \\
\hline 2 & 50 & $\mathrm{~F}$ & 1 & $1 \times M$ & $\mathrm{Y}$ & 18 \\
\hline 3 & 48 & $\mathrm{~F}$ & 15 & $2 \mathrm{xW}$ & $\mathrm{Y}$ & 14 \\
\hline 4 & 63 & $\mathrm{~F}$ & 1 & $1 \times D$ & $\mathrm{Y}$ & 16 \\
\hline 5 & 65 & M & 40 & $1 x \mathrm{~W}$ & $\mathrm{Y}$ & 22 \\
\hline 6 & 42 & $\mathrm{~F}$ & 20 & $1 \mathrm{x} W$ & $\mathrm{Y}$ & 23 \\
\hline 7 & 23 & $\mathrm{~F}$ & 10 & $1 \mathrm{x} W$ & $\mathrm{Y}$ & 17 \\
\hline 8 & 34 & $\mathrm{~F}$ & 20 & $1 \mathrm{x} W$ & $Y$ & 15 \\
\hline 9 & 56 & $\mathrm{~F}$ & 30 & 2x W & $\mathrm{N}$ & 17 \\
\hline 10 & 62 & $\mathrm{~F}$ & 7 & $1 \times D$ & $\mathrm{~N}$ & 10 \\
\hline 11 & 57 & $\mathrm{~F}$ & 20 & $2 \mathrm{xW}$ & Y & 22 \\
\hline 12 & 24 & $\mathrm{~F}$ & 12 & $1 \times 10 D$ & $Y$ & 24 \\
\hline 13 & 38 & $\mathrm{~F}$ & 5 & $1 \times 10 D$ & Y & 16 \\
\hline 14 & 51 & $\mathrm{~F}$ & 20 & $1 \mathrm{x} W$ & Y & 12 \\
\hline 15 & 52 & $\mathrm{~F}$ & 5 & $1 \times M$ & Y & 25 \\
\hline 16 & 47 & $\mathrm{~F}$ & 4 & $1 x W$ & $\mathrm{~N}$ & 15 \\
\hline 17 & 45 & $\mathrm{~F}$ & 1 & $1 \mathrm{x} W$ & Y & 20 \\
\hline 18 & 73 & $\mathrm{~F}$ & 30 & $1 \times M$ & $Y$ & 24 \\
\hline 19 & 66 & $\mathrm{~F}$ & 7 & $1 \mathrm{x} / 3 \mathrm{D}$ & Y & 13 \\
\hline 20 & 68 & M & 1 & $1 \mathrm{x} / 10 \mathrm{D}$ & $\mathrm{Y}$ & 17 \\
\hline 21 & 28 & $\mathrm{~F}$ & 3 & $1 \mathrm{x} / 10 \mathrm{D}$ & Y & 17 \\
\hline
\end{tabular}

(F: female, M: male, D: day, W: week; Y: yes, N: no) 
- Average of variation of the anal pressure due to the evacuation effort associated with the Valsalva maneuver in the proximal (V1) and distal (V2) regions of the anal canal;

- Average of variation of the anal pressure due to evacuation associated with post-expiration apnea in the proximal (A1) and distal (A2) regions of the anal canal;

- Calculation of area under the manometric track of the anal pressure variation during evacuation effort associated with the Valsalva maneuver (ARV) and during the evacuation effort with apnea postexpiratory (ARA) in the proximal (1) and distal (2) regions of the anal canal.

\section{The data obtained were:}

- Average anal pressures during rest, evacuation effort with the Valsalva maneuver and attempt to evacuate with postexpiratory apnea in proximal and distal channels.

- Average and standard deviation of the pressure variable comparatively per channel (proximal and distal) and moment ( R, V and A).

- Average and standard deviation of variable area at different times in the proximal and distal channels (ARV1, ARV2, ARA1, ARA2).

\section{Statistical analysis}

Comparative analysis was carried out using the variables obtained during different moments, in the proximal and distal anal canal, using descriptive statistics with values of averages, standard deviation, minimum, medium and maximum values. To study the variability of pressure on anal function of the factors moment and channel the analysis of variance (ANOVA) was used with two repeated factors and multiple comparison tests (ANOVA). Significance level was considered $5 \%(P$-value $\leq 0.05)$.

\section{RESULTS}

The manometric analysis of variable pressure $(\mathrm{mm} \mathrm{Hg})$ of the evacuation effort with the $\mathrm{V}$ moment and evacuation effort with A showed a tendency to be different $(P=0.0611)$, regardless of the channel. Among the proximal (1) and distal (2) channels there was a significant difference $(P=$
TABLE 3. ANOVA results - variable pressure

\begin{tabular}{lc}
\hline Effect & $\boldsymbol{P}$-value \\
\hline Channel & 0.0072 \\
Moment & $0.0611(\mathrm{~V} \neq \mathrm{A})$ \\
Channel and moment & 0.1647 \\
\hline $\mathrm{V}=$ evacuation effort with the Valsalva maneuver, $\mathrm{A}=$ evacuation effort with postexpiratory apnea
\end{tabular}

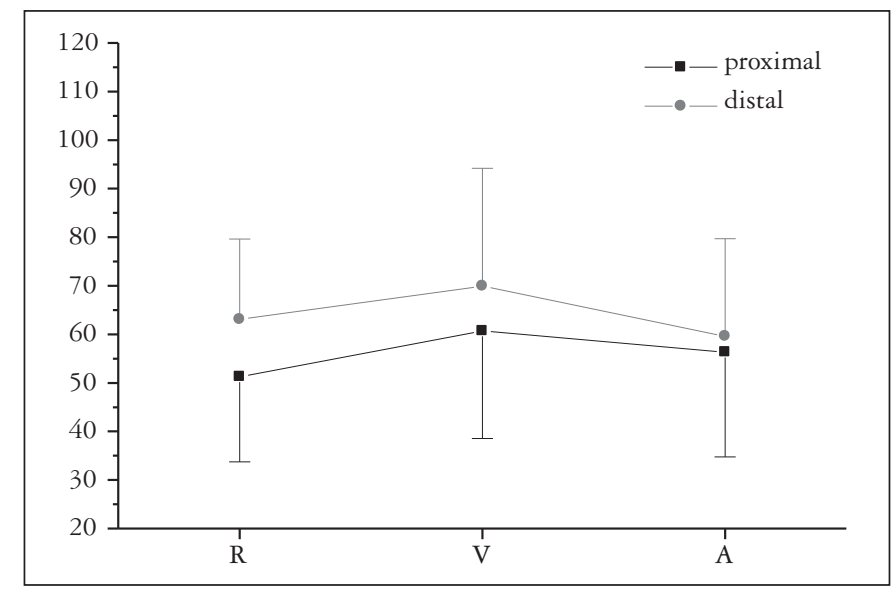

FIGURE 1. Average and standard deviation of the variable pressure by channel (proximal and distal) and moment $(\mathrm{R}=$ rest; $\mathrm{V}=$ evacuation effort with the Valsalva maneuver, $\mathrm{A}=$ evacuation effort with post-expiratory apnea)

0.0072), demonstrating that there is no interaction between channels and moments $(P=0.1647)$, as the channels behave in a different way, regardless of the moment (Table 2, 3, Figure 1).

The average of area values under the manometric track curve of the resting anal pressure variation $\left(\mathrm{mm}^{2}\right)$ showed no differences when compared to the proximal (1) and distal (2) channels $(P=0.10)$. Now the analysis of average values of area under the curve of the track at the moments studied (V and A), when compared, show statistically significant difference $(P=0.0008)$, confirming there is interaction of channels and moment $(P=0.0252)$ (Table 4, 5, Figure 2).

The Figures 3 and 4 are examples of the area under the curve of the track at the moments studied.

TABLE 2. Variable pressure $(\mathrm{mm} \mathrm{Hg})$ by channel and moment

\begin{tabular}{ccccccc}
\hline Variable & $\mathbf{n}$ & Average & DP & Minimum & Medium & Maximum \\
\hline R1 & 21 & 51.24 & 17.52 & 24.00 & 47.00 & 85.00 \\
V1 & 21 & 60.71 & 22.15 & 29.00 & 57.00 & 105.00 \\
A1 & 21 & 56.33 & 21.56 & 27.00 & 55.00 & 111.00 \\
R2 & 21 & 63.05 & 16.58 & 37.00 & 60.00 & 97.00 \\
V2 & 21 & 69.91 & 24.31 & 33.00 & 65.00 & 115.92 \\
A2 & 21 & 59.61 & 20.05 & 26.00 & 56.25 & 93.88 \\
\hline
\end{tabular}

$\mathrm{R} 1$ = resting anal pressure in the proximal region of the anal canal; V1 = anal pressure due to evacuation effort associated with the Valsalva maneuver in the proximal region of the anal canal; $\mathrm{A} 1=$ anal pressure due to evacuation effort associated with postexpiration apnea in the proximal region of the anal canal; $\mathrm{R} 2=$ resting anal pressure in the distal region of the anal canal; $\mathrm{V} 2=$ anal pressure due to the evacuation effort associated with the Valsalva maneuver in the distal region of the anal canal; A2 = anal pressure due to evacuation effort associated with postexpiration apnea in the distal region of the anal canal 
Benetti TH, Santos MF, Mergulhão MEA, Fagundes JJ, Ayrizono MLS, Coy CSR. Variation of the anal resting pressure induced by postexpiratory apnea effort in patients with constipation

TABLE 4. Variable area $\left(\mathrm{mm}^{2}\right)$ by channel and moment

\begin{tabular}{lcccccc}
\hline Variable & $\mathbf{n}$ & Average & DP & Minimum & Medium & Maximum \\
\hline ARV1 & 21 & 609.36 & 222.06 & 297.89 & 571.18 & 1049.86 \\
ARA1 & 21 & 563.05 & 218.62 & 267.48 & 527.88 & 1107.57 \\
ARV2 & 21 & 702.22 & 243.49 & 334.94 & 647.11 & 1159.05 \\
ARA2 & 21 & 597.93 & 204.50 & 253.99 & 562.40 & 942.38 \\
\hline
\end{tabular}

$\mathrm{ARV} 1$ = area under the manometric track of the anal pressure variation during evacuation effort associated with the Valsalva maneuver in the proximal region of the anal canal; ARA1 = area under the manometric track of the anal pressure variation during evacuation effort associated with apnea postexpiratory in the proximal region of the anal canal; ARV $2=$ area under the manometric track of the anal pressure variation during evacuation effort associated with the Valsalva maneuver in the distal region of the anal canal; ARA2 = area under the manometric track of the anal pressure variation during evacuation effort associated with apnea postexpiratory in the distal region of the anal canal.

TABLE 5. ANOVA results - variable area

\begin{tabular}{lc}
\hline Effect & $P$-value \\
\hline Channel & 0.1065 \\
Moment & 0.0008 \\
Channel and moment & 0.0252 \\
\hline
\end{tabular}

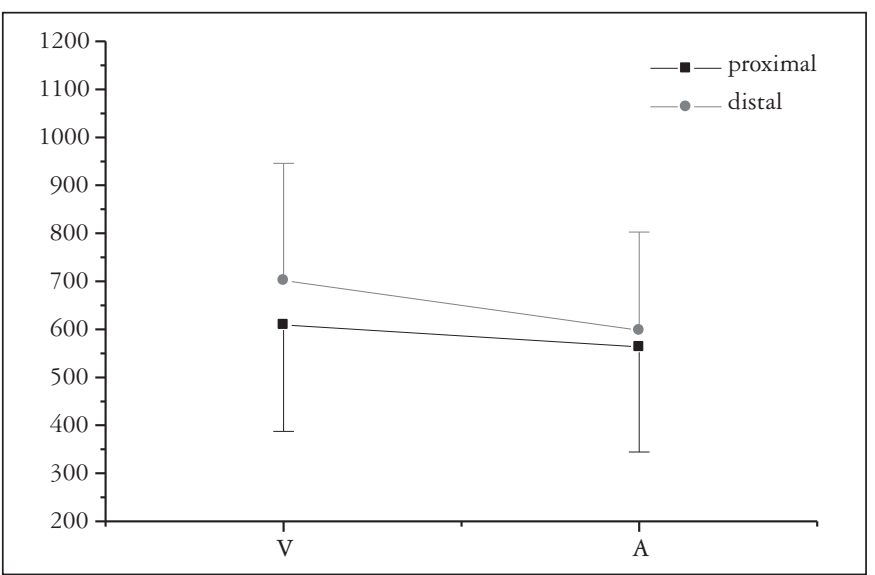

FIGURE 2. Average and standard deviation of the variable area by channel (proximal and distal) and moment $(\mathrm{V}=$ evacuation effort with the Valsalva maneuver, $\mathrm{A}=$ evacuation effort with post-expiratory apnea)

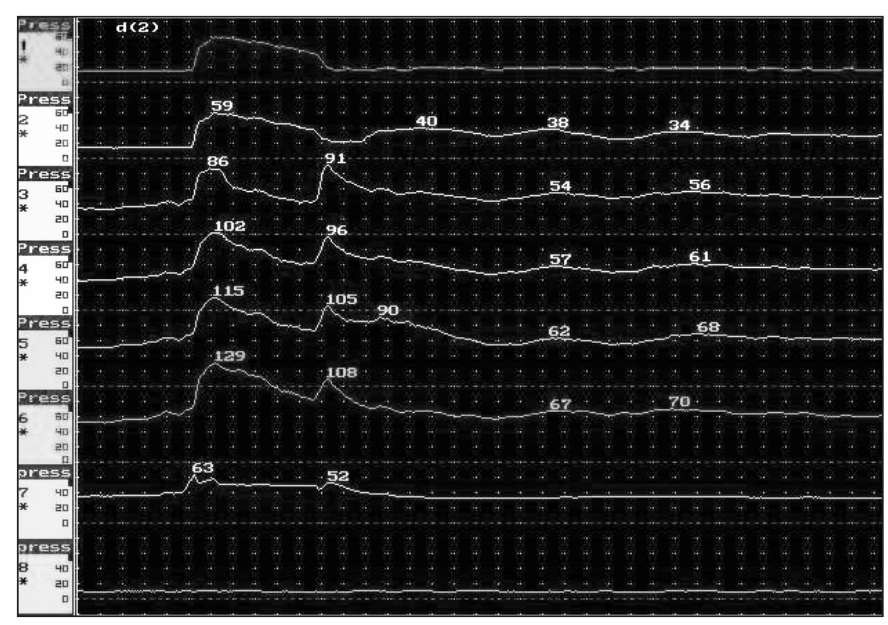

FIGURE 3. Manometric track: area under the curve of the resting anal pressure variation at the $\mathrm{V}$ moment

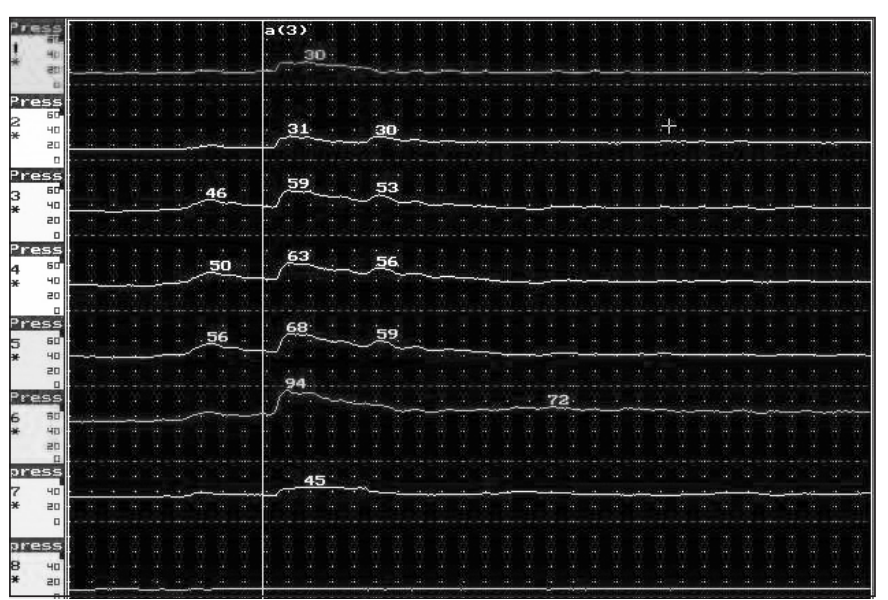

FIGURE 4. Manometric track: area under the curve of the resting anal pressure variation at the $\mathrm{A}$ moment

\section{DISCUSSION}

The fecal continence is acquired by a combination of competent anal sphincter, anorectal normal sensitivity, rectal capacity and appropriate compliance. Currently, the action of the muscles of the pelvic diaphragm in the mechanisms of continence and evacuation are also considered ${ }^{(2)}$, although the role of these on evacuatory disturbances is not fully known. Similarly, the etiology of functional constipation presents controversial aspects regarding the mechanisms etiopathogenic and diagnostic criteria ${ }^{(8)}$, in addition to treatment ${ }^{(18,22)}$. The observation that the $\mathrm{V}$, used by most patients at the end of the evacuation effort, could be an aggravating factor of the constipation, led to this study, to compare this variable with apnea after forced expiration. This presenting itself as a possible facilitator for the evacuation mechanism.

Anorectal manometry has been considered a useful examination to better understand the mechanisms related to the disorders of evacuation, allowing the correlation between the data and clinical observation ${ }^{(11,19,24)}$ and thus guide the conduct to be taken. Among the criteria used for the manometric diagnosis of functional constipation, is the elevation of the anal pressure during evacuation effort ${ }^{(16)}$. This study included patients with constipation, according to Agachan's score ${ }^{(1)}$ higher or equal than 10 and increase of the anal canal pressure during the effort of evacuation. The variables analyzed were the $\mathrm{V}$ and $\mathrm{A}$ after forced expiration in two distinct portions of the anal canal.

The analysis of average values of resting anal pressure identified that they are lower in the proximal anal canal than 
the distal anal canal, probably as the pressure in the distal portion suffers greater influence from the voluntary control of pelvic muscles, which tends to remain in a state of contraction in patients with constipation by dyskinesia of the pelvic floor. This fact could explain the observation that the pressure values of the anal canal during the evacuation effort tend to be different when comparing moments $\mathrm{V}$ and $\mathrm{A}(P=0.0611)$, indicating that post-expiratory apnea could be related to the decrease of abdominal press, as well as lead to a relaxation of the muscles of the anal canal. Similar results were obtained by Giannantoni et al. ${ }^{(9)}$ and Nagib et al. ${ }^{(13)}$, showing that during the $\mathrm{V}$ there was simultaneous contraction of the muscles of the pelvic floor, as demonstrated by the significant increase in electromyographic activity and rectoanal pressure gradient. In this study, as regards the variable pressure, there was no significant interaction between the proximal and distal regions and moments, which could lead to the interpretation that the distinct portions of the anal canal behave similarly in both $\mathrm{V}$ and on $\mathrm{A}$ post forced expiration (Table 2).

The analysis of variable area under the curve at the moment $\mathrm{A}$ in relation to $\mathrm{V}$ in the distal anal canal allowed the identification of lower values in A, or a tendency to relax the muscles with this maneuver. The comparison of the moments $\mathrm{A}$ and $\mathrm{V}$ in the proximal and distal positions of the anal canal showed greater relaxation distally in $\mathrm{A}$, demonstrating that the various portions of the anal canal were behaving differently.

The data show the occurrence of greater relaxation in the proximal portion of the anal canal in both moments. This physiological event is important to allow the rectal contents (gas and feces), contact with sensory nerve endings in that region, providing discrimination of the rectal contents and thus trigger the excitatory stimuli rectal motility.

This study showed that the evacuation effort associated with the postexpiration apnea could induce the relaxation of the muscles of the pelvic floor during the evacuation, making it easier for patients with of constipation by dyskinesia of the pelvic floor. This is a simple to understand and applicate in daily routine and when constantly practiced and with adequate orientation can promote better sensory-motor awareness in constipated patients, and therefore clinical improvement. Thus, this technique can be used as a basis for developing a program of conservative treatment such as biofeedback.

We found no similar studies in literature rendering a comparative analysis impossible. However, it is known that the evacuation is usually triggered by the association of effort with the $\mathrm{V}$ and relaxation of the muscles of the pelvic floor. Constipation in patients with dyskinesia of the pelvic floor tends to have decreased rectal sensitivity and muscular incoordination during the act of evacuation, showing an unconscious paradoxical contraction, exacerbated by the $\mathrm{V}$.

Biofeedback could be used as a treatment for various types of muscle dysfunctions and is widely used in medicine. This technique has positive results in functional recovery, mainly due to the information provided to patients by various stimuli (visual, auditory, sensory), which cannot be obtained in other ways ${ }^{(23)}$. This therapy can be used in different ways, but the analysis of the literature shows the presence of little informative data concerning the description of this type of treatment ${ }^{(10,12,23)}$ or the exact technique and the presentation of results obtained in the long term.

Although most studies show positive results using the biofeedback technique in the treatment of dyskinesia of the pelvic floor, the data regarding the etiology and severity of symptoms, criteria for selection of patients and the definition of a successful result is somewhat inconsistent, signaling the need for further research of this subject ${ }^{(10)}$. The search for better understanding of the etiopathogenic mechanisms related to functional constipation, through specific studies in laboratories of anorectal physiology, will enable to obtain increasingly efficient therapeutic results.

\section{CONCLUSION}

The effort of evacuation associated with postexpiratory apnea, when compared with the effort associated with the Valsalva maneuver, provides lower elevation of anal pressure at rest by the parameter area under the curve.

Benetti TH, Santos MF, Mergulhão MEA, Fagundes JJ, Ayrizono MLS, Coy CSR. Variação da pressão anal de repouso induzida pela apneia pós-esforço expiratório em pacientes com constipação intestinal. Arq Gastroenterol. 2011;48(1):30-5 .

RESUMO - Contexto - A constipação intestinal é um sintoma comum na população, sendo mais frequente em mulheres, podendo ser secundária a erro alimentar, distúrbios orgânicos ou funcionais. Dentre estes, destaca-se a discinesia do assoalho pélvico, caracterizada basicamente por ausência de relaxamento ou contração paradoxal da musculatura pélvica e do canal anal no momento da evacuação. O melhor conhecimento dos mecanismos envolvidos na constipação de etiologia funcional pode contribuir em terapêuticas mais eficazes. Objetivo - Analisar através de dados manométricos, a variação da pressão anal de repouso durante o esforço de evacuação com a manobra de Valsalva e apneia pós-expiração forçada em pacientes com constipação. Métodos - Foram estudados 21 pacientes, com idade média de 47,5 (23-72) anos, sendo 19 (90,4\%) do sexo feminino. Empregou-se manometria anorretal com cateter de oito canais dispostos no eixo axial, realizando-se as medidas na porção proximal (1) e distal (2) do canal anal. Todos os pacientes apresentavam elevação dos valores pressóricos em relação ao repouso com esforço de evacuação e para a avaliação do grau de constipação, empregou-se o escore de Agachan. As variáveis estudadas foram: pressão anal média do canal anal por 20 segundos em repouso, ao esforço de evacuação com manobra de Valsalva (V) e ao esforço de evacuação em apneia após expiração forçada (A), assim como a área sob a curva do traçado manométrico nos momentos $\mathrm{V}$ e $\mathrm{A}$. Resultados - $\mathrm{A}$ análise dos valores médios da variação da pressão anal de repouso evidenciou diferença entre os canais proximais e distais $(P=0,007)$, independente do momento, e tendência à diferença nos momentos $\mathrm{V}$ e $\mathrm{A}$ $(P=0,06)$. A média dos valores da área sob a curva do traçado manométrico demonstrou diferença entre os momentos $\mathrm{V}$ e $\mathrm{A}(P=0,0008)$, tanto na porção proximal como na porção distal do canal anal. Conclusão - O esforço de evacuação associado à apneia pós-expiração quando comparada ao esforço de evacuação associado à manobra de Valsalva, proporciona menor contração do canal anal pela análise do parâmetro área sob a curva.

DESCRITORES - Constipação intestinal. Manometria. Discinesia. 


\section{REFERENCES}

1. Agachan F, Cheng T, Pfeifer J, Reissman P, Wexner SD. A constipation score system to simplify evaluation and management of constipated patients. Dis Colon Rectum. 1996;39:681-5.

2. Andromanakos N, Skandalakis P, Troupis T, Filippou D. Constipation of anorectal outlet obstruction: pathophysiology, evaluation and management. J Gastroenterol Hepatol. 2006;21:638-46.

3. Berman L, Aversa J, Abir F, Longo WE. Management of disorders of the posterior pelvic floor. Yale J Biol Med. 2005;78:211-21.

4. Bouchoucha M, Devroede G, Arsac M. Anismus: a marker of multi-site functional disorders? Int J Colorectal Dis. 2004;19:374-9.

5. D'Hoore A, Penninckx F. Obstructed defecation. Colorectal Dis. 2003;5:280-7.

6. Duthie GS, Bartolo DC. Anismus. the cause of constipation? Results of investigation and treatment. World J Surg. 1992;16:831-5.

7. Farid M, Youssef T, Mahdy T, Omar W, Moneim HA, El Nakeeb A, Youssef M. Comparative study between botulinum toxin injection and partial division of puborectalis for treating anismus. Int J Colorectal Dis. 2009;24:327-34.

8. Foxx-Orenstein AE, Mcnally MA, Odunsi ST. Update on constipation: one treatment does not fit all. Cleve Clin J Med. 2008;75:813-24.

9. Giannantoni A, Di Stasi SM, Cucchi A, Mearini VB, Porena M. Pelvic floor muscle behavior during Valsalva leak point pressure measurement in males and females affected by stress urinary incontinence. J Urol. 2003;170:485-9.

10. Heymen S, Jones KR, Scarlett Y, Whitehead WE. Biofeedback treatment of constipation - a critical review. Dis Colon Rectum. 2003;46:1208-17.

11. Leal VM, Coy CSR, Fagundes JJ, Ayrizono MLS, Góes JRN. Estudo de parâmetros do reflexo inibitório retoanal em multíparas, na zona de alta pressão com catéter radial. Rev Bras Coloproctol. 2006;26:293-9.

12. Lehur PA, Stuto A, Fantoli M, Villani RD, Queralto M, Lazorthes F, Hershman M, Carriero A, Pigot F, Meurette G, Narisetty P, Villet R. Outcomes of stapled transanal rectal resection vs. biofeedback for the treatment of outlet obstruction associated with rectal intussusception and rectocele: a multicenter, randomized, controlled trial. Dis Colon Rectum. 2008;51:1611-8.

13. Nagib ABL, Guirro ECO, Palauro VA, Guirro RRJ. Avaliação da sinergia da musculatura abdômino-pélvica em nulíparas com eletromiografia e biofeedback perineal. Rev Bras Ginecol Obstet. 2005;27:210-5.

14. Pescatori M, Spyrou M, Pulvirenti d'Urso A. A prospective evaluation of occult disorders in obstructed defecation using the 'iceberg diagram'. Colorectal Dis. 2006;8:785-9.
15. Preston DM, Lennard-Jones JE. Anismus in chronic constipation. Dig Dis Sci. 1985;30:413-8

16. Rao SS, Welcher K, Leistikow J. Obstructive defecation: a failure of rectoanal coordination. Am J Gastroenterol. 1998;93:1042-50.

17. Rao SS, Hatfield R, Soffer E, Raos S, Beaty J, Conklin JL. Manometric tests of anorectal function in healthy adults. Am J Gastroenterol. 1999;94:773-83.

18. Rao SS. Dyssyrnegic defecation and biofeedback therapy. Gastroenterol Clin North Am. 2008;37:569-86.

19. Saad LH, Coy CS, Fagundes JJ, Ariyzono Mde L, Shoji N, Góes JR. [Sphincteric function quantification by measuring the capacity tosustain the squeeze pressure of the anal canal]. Arq Gastroenterol. 2002;39:233-9.

20. Sapsford RR, Hodges, PW. Contraction of the pelvic floor muscles during abdominal maneuvers. Arch Phys Med Rehabil. 2001;82:1081-8.

21. Schouten WR, Briel JW, Auwerda JJ, van Dam JH, Gosselink MJ, Ginai AZ, Hop WC. Anismus: fact or fiction? Dis Colon Rectum. 1997;40:1033-41.

22. Succi L, Oliveri CE, Privitera AC, Randazzo G, Ohazuruike NL, Prumeri S, Politi A. Treatment strategies for chronic constipation: our experience. Chir Ital. 2008;60:509-18.

23. Vickers DE. Biofeedback for constipation. In: Wexner SD, Duthie D, Bartolo CDD, editors. Constipation: etiology, evaluation, and management. 2nd ed. London: Springer;2006. p.117-34

24. Vieira EP, Pupo Neto JA, Lacombe DLP. Contribuição da manometria ano retal na avaliação da constipação intestinal crônica. Rev Bras Coloproctol. 2005;25:348-60.

25. Voderholzer WA, Neuhaus DA, Klauser AG, Tzavella K, Müller-Lissner SA, Schindlbeck NE. Paradoxical sphincter contraction is rarely indicative of anismus. Gut. 1997:41:258-62

26. Wald A, Caruana BJ, Freimanis M, Bauman DH, Hindis JP. Contributions of evacuation proctography and anorectal manometry to the evaluation of adults with constipation and defecatory difficulty. Dig Dis Sci. 1990;35: 481-7

27. Wasserman IF. Puborectalis syndrome (rectal stenosis due to anorrectal spasm) Dis Colon Rectum. 1964; 7:87-98.

28. Wexner SD, Duthie GS Bartolo CDD. Constipation: etiology, evaluation, and management. 2nd ed. London: Springer; 2006. 265p.
Received 11/5/2010. Accepted 15/10/2010 